https://doi.org/10.15407/frg2020.05.371

UDC 581.132

\title{
INFLUENCE OF DROUGHT ON THE PHOTOSYNTHETIC APPARATUS ACTIVITY, SENESCENCE RATE, AND PRODUCTIVITY IN WHEAT PLANTS
}

\author{
O.O. STASIK, D.A. KIRIZIY, O.G. SOKOLOVSKA-SERGIIENKO, \\ O.Yu. BONDARENKO
}

Institute of Plant Physiology and Genetics, National Academy of Sciences of Ukraine 31/17 Vasylkivska St., Kyiv, 03022, Ukraine

e-mail: phot-ecol@ifrg.kiev.ua

Effects of soil drought at flowering stage on the functional state of photosynthetic apparatus and chloroplast enzymatic antioxidant defense systems in flag leaf during reproductive period, and the productivity of winter wheat plants of high-protein Natalka variety and drought-tolerant Podolyanka variety were studied in pot experiment. Until flowering and for the control plants during the entire vegetation, the soil moisture content was maintained at a level of $60-70 \%$ of field capacity (FC). Drought treatment (soil moisture $30 \%$ FC) was applied for 7 days covering flowering-early kernel watery ripe period (BBCH 61-71). After that, watering of plants was resumed to a control level which was maintained until the end of the growing season. The estimation of the chlorophyll and Rubisco content, the chloroplast antioxidant enzymes activity, and the net $\mathrm{CO}_{2}$ assimilation and transpiration rates was carried out on flag leaves. The measurements were taken on the third day of watering cessation (the first day the soil moisture reached $30 \% \mathrm{FC}, \mathrm{BBCH} 61$ ), at the end of the drought period (seventh day at $30 \% \mathrm{FC}, \mathrm{BBCH} 71)$, and after watering resumed at the medium milk (BBCH $75)$ and late milk (BBCH 77) stages. The components of plant grain productivity were determined by weighing air-dry material at grain full ripeness. It was revealed, that drought stress during flowering inhibited $\mathrm{CO}_{2}$ assimilation and accelerated induction of senescence processes in wheat plants associated with degradation of photosynthetic apparatus and manifested in quicker ontogenetic drop in chlorophyll and Rubisco contents and loss of leaf photosynthetic activity. This exacerbated the drought impact on the plant organism so that after optimal watering return, the physiological and biochemical parameters were not restored to the values of control plants that were all time under optimal moisture supply. Stress-induced premature senescence reduced the supply of plants with assimilates and ultimately led to a decrease in their grain productivity. Impact of drought on flag leaf photosynthetic activity and especially on senescence induction were much more pronounced in the high-protein wheat variety Natalka with a genetically programmed earlier start of the nitrogen-containing compounds remobilization from leaves than in Podolyanka variety. The drought-tolerant variety Podolyanka keep ability to maintain much higher $\mathrm{CO}_{2}$ assimilation activity during drought period and to preserve photosynthetic apparatus from early

Citation: Stasik O.O., Kiriziy D.A., Sokolovska-Sergiienko O.G., Bondarenko O.Yu. Influence of drought on the photosynthetic apparatus activity, senescence rate, and productivity in wheat plants. Fiziol. rast. genet., 2020, 52, No. 5, pp. 371-387. https://doi.org/10.15407/frg2020.05.371 
induction of senescence due to likely more efficient chloroplast antioxidant defense systems, thereby gaining a better assimilates supply for yield formation.

Key words: Triticum aestivum L., drought, senescence, $\mathrm{CO}_{2}$ assimilation rate, Rubisco, antioxidant enzymes, productivity.

Nowadays, the main problem in plant sciences is the development of technologies that will increase food production and ensure the sustainability of crop yield, especially in the context of global climate change [1]. Recent findings show that yield and nutritional value, as well as resistance to stress, can be changed by regulating the senescence of plant organism [2].

The natural plant senescence syndrome in many molecular and phenotypic aspects resembles the response of plants to abiotic stresses [3, 4]. It is often difficult to separate the effects of age-related senescence from senescence caused by stress, since both affect many similar biochemical processes and ultimately lead to plant death [3]. Both processes are of global agro-economic importance, since early senescence of plants is the main cause of losses during grain filling and in biomass growth due to decrease in photosynthesis because of leaves yellowing. Abiotic stresses can exacerbate dramatically yield losses [5].

Leaf senescence is characterized by a decrease in the leaf chlorophyll content and photosynthetic rate [6], and includes cell organelles autophagy and other processes of programmed cell death [7]. However, leaf senescence is not only a destructive process, but also plays a vital role in the recycling of nutrients, especially in nitrogen remobilization $[8,9]$. During natural senescence, the nitrogen remobilization from the photosynthetic apparatus requires that the cell membranes remain intact and, unlike cell death under the influence of a stressor, cell compartmentalization persists until the last stages.

The onset of leaf senescence should be optimized depending on environmental conditions [8]. Too early senescence will reduce the plant overall ability to absorb $\mathrm{CO}_{2}$, while too late senescence will interfere with nutrient remobilization, thereby disrupting the maturation of the reproductive organs. It can be expected that the early onset of senescence will be favorable when the availability of photoassimilates is high or when the supply of inorganic nutrients such as nitrogen is low. Therefore, leaf senescence is considered as a plastic feature that can regulate adaptation to growth conditions, thereby maintaining the overall plant carbon and nitrogen balance [2].

The study of the mechanisms that control senescence is hampered by the fact that senescence is a gradual process and therefore difficult to quantify $[4,5]$. In addition, senescence can be caused by many different factors, and a complex system of signaling pathways is involved in its regulation [3]. So, the leaves senescence rate is affected by light conditions, $\mathrm{CO}_{2}$ concentration, nitrogen supply, water and salt stresses, as well as infection by pathogenic microorganisms.

The reactive oxygen species (ROS) generation is one of the earliest plant cell responses to abiotic stress and senescence [10, 11, 12]. Plants adapt to the stressful effects of the environment through an acclimation process that includes effective control of the ROS generation in combination with antioxidant protection [13]. The latter is also a characteristic of 
wheat genotypes exhibiting stay-green phenotype, that is, the ability to retain green leaves for a long time during fruit formation [11]. Chloroplasts are the main site of protein degradation in leaf cells, and Rubisco quickly and selectively degrades during senescence and stress [10]. The process of protein degradation is initiated by ROS, and includes the action of proteolytic enzymes.

Drought-induced stress encompasses reactions ranging from modifying the patterns of gene expression to changes in metabolism and plant growth [5]. Drought can initiate and accelerate leaf senescence, as a result of which the leaf area index, net assimilation and productivity are reduced. The water stress effect on the endogenous level of plant hormones in relation to senescence was studied for cytokinin, auxin, gibberellin, salicylic and jasmonic acids, ethylene, brassinosteroids, and, perhaps, the deepest for abscisic acid (ABA) [14]. It was revealed that the increase in the ABA content caused by drought positively correlated with the remobilization of carbon from senescent leaves into grain in wheat plants [15]. On Arabidopsis, it have been shown that when plants are exposed to drought, ABA signals trigger ROS accumulation mediated by the transcription factor NTL4/NAC053, which binds directly to promoters of genes encoding ROS biosynthesis enzymes, which leads to the induction of leaf senescence [16].

The aim of our work was to study the peculiarities of soil drought impact during flowering on the dynamics of photosynthetic apparatus functional state, the pro/antioxidant status of flag leaves during grain filling, and the productivity of high-protein and drought-tolerant winter wheat varieties.

\section{Materials and methods}

The research was carried out with bread winter wheat plants (Triticum aestivum L.) of Podolyanka and Natalka varieties grown in pots with $10 \mathrm{~kg}$ of fertilized soil at natural light. Fertilizers were added in equal quantities $\left(\mathrm{N}_{80} \mathrm{P}_{80} \mathrm{~K}_{80}+\mathrm{N}_{80} \mathrm{P}_{80} \mathrm{~K}_{80} \mathrm{mg} / \mathrm{kg}\right.$ of soil) when the pots were filled with soil, and at the middle of the stem elongation period (BBCH 34). For each variety, 10 pots with 20 plants each were set up.

Until flowering, and for the control plants during the entire growing season, the moisture content of the soil was maintained at a level of $70 \%$ of field capacity (FC). Drought treatment was applied to one half of the pots at the start of flowering stage. Another half of pots were used as a watered control. The plants were exposed to soil drought during flowering-kernel watery ripe period $(\mathrm{BBCH} 61-71)$ by withholding watering plants and reducing the soil moisture within three days to the level of $30 \%$ FC, which was maintained for the next seven days. After that, watering plants was resumed to a control level that was maintained until the end of the growing season. The soil moisture in the pots was controlled gravimetrically $1-2$ times a day.

The determination of the $\mathrm{CO}_{2}$ assimilation rate, transpiration rate, contents of chlorophyll and Rubisco as well as the chloroplasts antioxidant enzymes activity were carried out using flag leaves. Measurements were taken on the third day of watering cessation (the first day the soil moisture reached $30 \% \mathrm{FC}, \mathrm{BBCH} 61$ ), at the end of the drought period (seventh day at $30 \% \mathrm{FC}, \mathrm{BBCH} 71$ ), and after control watering regime resumed at 
the medium milk (BBCH 75) and late milk (BBCH 77) stages. The indices of control plant leaf were determined at the same time. The components of plant grain productivity were determined by weighing air-dry material after achieving the grain full ripeness.

The total chlorophyll content in the leaf lamina was determined by the non-maceration method by extraction with dimethyl sulfoxide, followed by determination of the extracts extinction coefficients using spectrophotometer [17].

The net $\mathrm{CO}_{2}$ assimilation rate $\left(\mathrm{A}_{\mathrm{N}}\right)$ was recorded under controlled conditions using an infrared gas analyzer GIAM-5M (Russia). The intact flag leaves $\left(2\right.$ in parallel) were placed in a temperature-controlled $\left(+25^{\circ} \mathrm{C}\right)$ chamber $(3 \times 7 \mathrm{~cm})$ and illuminated $\left(1800 \mu \mathrm{mol} /\left(\mathrm{m}^{2} \cdot \mathrm{s}\right)\right.$ PAR $)$ by the TA$1150 \mathrm{~W}$ LED spotlights with a light temperature of $5200 \mathrm{~K}$. Atmospheric air was blown through the chamber at a speed of $1 \mathrm{l} / \mathrm{min}$. The transpiration rate was measured by a portable gas analyzer EGM 5 (USA) based on the difference in air humidity at the inlet and outlet of the chamber. Gas exchange parameters were calculated according to standard methods [18].

Rubisco content in the leaves was determined by quantitative electrophoresis [19]. The protein was extracted into $5 \mathrm{ml}$ of a buffer solution containing $50 \mathrm{mM}$ Tris- $\mathrm{HCl}(\mathrm{pH} 7.8), 2 \mathrm{mM} \mathrm{MgCl} 2,1 \mathrm{mM}$ EDTA. The homogenate was centrifuged at $1200 \mathrm{~g}$ and a temperature of $+4{ }^{\circ} \mathrm{C}$ for $10 \mathrm{~min}$. Protein electrophoresis was performed according to the Laemmli method [20]. The mixture of the protein preparation with denaturing buffer contained: Tris- $\mathrm{HCl}(\mathrm{pH} 6.8)-0.125 \mathrm{M}, 2$-mercaptoethanol $-10 \%$, glycerol $-10 \%$, SDS $-2 \%$, bromphenol blue $-0.2 \%$. Samples were applied to the wells on a polyacrylamide plate consisting of a concentrating $4 \%$ gel and a separating $12.5 \%$ gel. Three calibration samples of bovine serum albumin (BSA) of known different concentrations were applied to each plate. Electrophoresis was performed at a current of $10 \mathrm{~mA}$ until the bromphenol blue completely penetrated the gel, and then at $5 \mathrm{~mA}$. After electrophoresis, the gel was stained in a $0.1 \%$ Brilliant Blue solution, followed by washing the gel in a solution of $10 \%$ acetic acid and $10 \%$ ethyl alcohol. The gels were scanned and the color intensity of the large Rubisco subunit bands was determined using the Gel-ProAnalyzer program, and the contents were calculated from the calibration relation for BSA.

For the determination of antioxidant enzymes activity, chloroplasts were isolated mechanically at a temperature of $0-4{ }^{\circ} \mathrm{C}$. The sample $(2 \mathrm{~g})$ of wheat leaves was homogenized in a 7-fold volume of buffer solution of the following composition: $0.33 \mathrm{M}$ sorbitol, $5 \mathrm{mM} \mathrm{MgCl}, 0.1 \% \mathrm{BSA}, 4 \mathrm{mM}$ ascorbic acid and $50 \mathrm{mM}$ Tris- $\mathrm{HCl}(\mathrm{pH} 7.5)$. The homogenate was filtered through two layers of nylon fabric and centrifuged in a centrifuge K-24D at $80 \mathrm{~g}$ and a temperature of $0-4{ }^{\circ} \mathrm{C}$ for 5 minutes to precipitate heavy particles. The supernatant was poured into other pre-cooled centrifuge tubes and centrifuged at $2000 \mathrm{~g}$ for 10 minutes to obtain a fraction of chloroplasts. The chloroplasts sediment was resuspended in isotonic medium with $4 \mathrm{mM}$ ascorbic acid, $50 \mathrm{mM}$ Tris- $\mathrm{HCl}(\mathrm{pH} \mathrm{7.5)}$ in a volume of $2 \mathrm{ml}$ and subsequently used to determine the activity of superoxide dismutase (SOD) and ascorbate peroxidase (APX). 
The superoxide dismutase (SOD, EC 1.15.1.1) activity was determined spectrophotometrically using nitrotetrazolium blue at a wavelength of $560 \mathrm{~nm}$ [21]. The ascorbate peroxidase (APX, EC 1.11.1.11) activity was measured in the ultraviolet region of the spectrum at $290 \mathrm{~nm}$ using the Chen \& Asada method [22].

Analytical repeatability of photosynthetic pigments content determination using pooled sample of leaves of 5 individual plants -3 -fold, determination of gas exchange, Rubisco content, and enzymes activity - 4-fold. Data on components of grain productivity were determined as average of measurements of 20 individual plants. The obtained data were processed by generally accepted methods of variation statistics. The figures and the tables show the arithmetic mean and standard error of the mean. The significance of the difference between controls and treatments were evaluated using ANOVA. Differences were considered significant at $\mathrm{p} \leq 0.05$.

\section{Results and discussion}

In general, the dynamics of the total chlorophyll content in the flag leaves of control plants of both varieties was similar: the maximum was observed at $\mathrm{BBCH} 71$ stage, followed by an accelerating decline (Fig. 1). However the rate of the decline was significantly different. Thus, the chlorophyll content in flag leaf at BBCH 75 stage decreased by $33 \%$ compared with the maximum value in Natalka variety and only by $11 \%$ in Podolyanka variety. Then at BBCH 77 stage, the chlorophyll content in Natalka variety decreased by almost 6 times compared with $\mathrm{BBCH} 71$ stage, while in Podolyanka variety - by 3 times.

Such differences in the chlorophyll content decline might be explained by the genotypic peculiarities of the studied varieties related to their economic use: Podolyanka is a drought-tolerant variety with high ecological plasticity and stay-green traits providing stable high yield under a wide range of growing conditions, whilst Natalka is a high-protein-content variety with excellent seed baking qualities [23]. It is known that protein-gluten complex formation in wheat varieties with high grain quality is
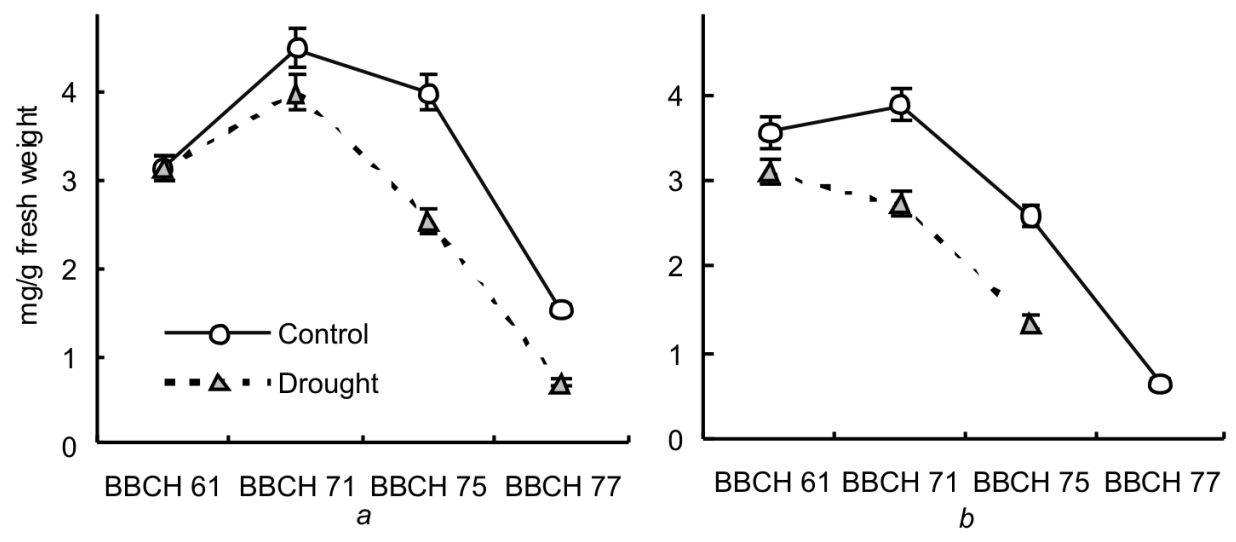

Fig. 1. The total chlorophyll content in the flag leaves of control and drought-treated (during $\mathrm{BBCH}$ 61-71 stages) wheat plants: $a-$ Podolyanka, $b-$ Natalka 
accompanied by intensive remobilization of nitrogen-containing compounds from vegetative organs, primarily from leaves [24]. Since most of the leaf nitrogen is concentrated in the proteins of photosynthetic apparatus, grain filling in high protein varieties is accompanied by accelerated degradation of photosynthetic structures and enzymatic complexes [25]. One of the manifestation of these processes is a decrease in the chlorophyll content [6]. Nitrogen remobilization processes are primarily associated with an increase in the proteolytic enzymes activity and are similar to the processes of natural senescence and programmed cell death [26]. Their similarities and differences, as noted in the introduction, are actively discussed in the literature, since the management of their mechanisms will give new approaches to increasing the yield and quality of plant products, in particular wheat grain.

At the same time, the stay-green phenotype is most pronounced in preserving the chlorophyll content in the leaves until the last stages of grain filling and ripening, and is associated with increased resistance to stress factors, especially drought $[27,28]$. Provided the spike highly attracting ability and the photosynthetic apparatus assimilation activity, this leads to an increase in grain productivity. However, the grain protein content may decrease due to the «dilution» with carbohydrates. It was also noted the presence among stay-green wheat genotypes those able to absorb intensively mineral nitrogen from the soil, provided that this element is well supplied, and to assimilate it efficiently which contributes to an increase in the grain protein content [29]. If the spike attracting ability is insufficient to utilize all assimilates produced by the stay-green photosynthetic apparatus, their excess accumulates in the vegetative organs, and yield does not increase [30].

Numerous published data reveal that under stress conditions, senescence processes may begin earlier and proceed faster than under normal ones [3, 5, 31]. Indeed, in our experiments, the chlorophyll content in the flag leaf of drought-treated plants of both varieties was lower than in the control ones (see Fig. 1). Moreover, even after the resumption of normal watering, this index in treated plants continued to be lower than the corresponding control values. Consequently, considering the content of the main photosynthetic pigments, the drought has launched irreversible processes of photosynthetic apparatus degradation, outwardly very similar to those observed during natural senescence under normal conditions.

At the same time, differences between varieties in the drought effects on the flag leaf pigment content were observed. In Podolyanka variety, the chlorophyll content did not practically differ from the control at the first day of reaching soil moisture of $30 \% \mathrm{FC}$ and only after a week growing at this level of soil moisture it was less than the corresponding control value by $11 \%$. However in stressed plants of Natalka variety, chlorophyll content on the first day of drought was $13 \%$ lower than the control, and almost $30 \%$ on the seventh. After the soil moisture for treated plants was restored to $70 \% \mathrm{FC}$, the chlorophyll content in the leaf at $\mathrm{BBCH} 75$ stage was $36 \%$ lower than the control in Podolyanka variety, and $48 \%-$ in Natalka variety. In the treated plants of the last variety, the leaves at $\mathrm{BBCH} 77$ stage lost almost all their green color and, therefore, the chlorophyll content in them was not determined. At the same time, the leaves of 
the treated plants of Podolyanka variety still contained some chlorophyll, although its level was 2.2 times lower than in the control.

In general, the chlorophyll content in the leaves of control and trea ted plants of Podolyanka variety was higher than that of Natalka variety during all experiment except stage $\mathrm{BBCH}$ 61. That is, the varietal peculiarities noted above (stay-green trait in Podolyanka variety and rapid degradation of the pigment apparatus after flowering in Natalka variety) were retained in treated plants. The drought treatment accelerated chlorophyll content decline during grain formation and filling almost in parallel to the control indices. Therefore, it can be assumed that some stress responses of drought-treated plants may serve as a trigger for the earlier start of irreversible senescence processes. This, in our opinion, explains the lack of chlorophyll content restoration in the leaves of treated plants after the resumption of normal watering. Moreover, in plants of the high-protein variety Natalka with a genetically programmed earlier start of the nitrogencontaining compounds remobilization from leaves, the senescence of treated plants began earlier than in the drought-tolerant Podolyanka variety. In treated plants of the latter one, it was even observed an increase in chlorophyll content at the end of the drought period compared with its onset, slightly lower than it was spotted for control plants for this period. The fall in chlorophyll content in treated plants of Podolyanka variety started only after the end of the drought period, whilst in Natalka plants, such irreversible decline was observed already on the beginning of drought.

The $\mathrm{CO}_{2}$ assimilation rate dynamics in flag leaf of control plants during the studied period differed somewhat comparing to the changes of the chlorophyll content (Fig. 2). The $\mathrm{CO}_{2}$ assimilation in Podolyanka variety remained almost at the same level during $\mathrm{BBCH} 61-75$ stages, and only at BBCH 77 stage a sharp decrease was observed. At the same time, in control plants of Natalka variety, the photosynthetic rate after flowering gradually decreased with acceleration to the $\mathrm{BBCH} 77$ stage. These results fit well with the notion about stay-green traits of the first variety, and the earlier beginning of the remobilization in second one, which is undoubtedly accompanied by a complex of processes characterized as senescence.
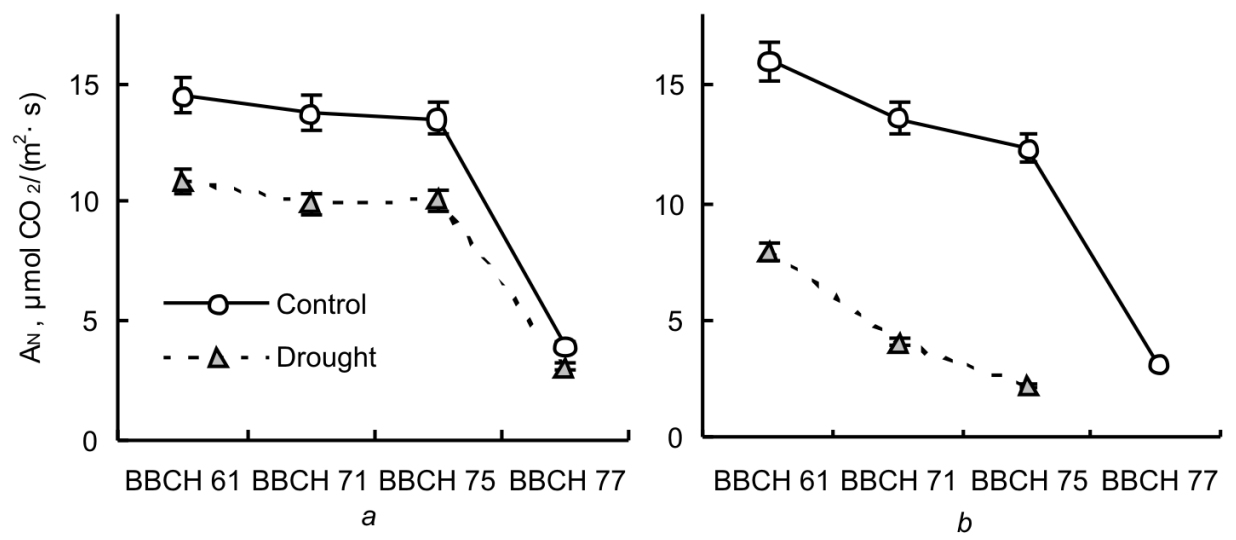

Fig. 2. The net $\mathrm{CO}_{2}$ assimilation rate $\left(\mathrm{A}_{\mathrm{N}}\right)$ in the flag leaves of control and drought-treated (during BBCH 61-71 stages) wheat plants: $a-$ Podolyanka, $b-$ Natalka 
The photosynthetic rate dynamics in flag leaf of treated plants of Podolyanka variety was similar to the control, however, the values of $\mathrm{CO}_{2}$ assimilation rate amounted to $72-75 \%$ of the control (see Fig. 2). After the normal irrigation resumption, the photosynthetic rate at $\mathrm{BBCH} 75$ stage remained at the level corresponding for the drought period (i.e., there was no recovery). However, it should be noted that, having decreased already at the beginning of the stress, the $\mathrm{CO}_{2}$ assimilation in Podolyanka remained quite stable until drought-treatment end, which was one of the most prominent differences between varieties in their reaction to drought. Thus, in Natalka variety plants, the photosynthetic rate on the first day of reducing soil moisture to $30 \%$ FC fell by 2 times compared to the control, and then, to the end of the drought period - by 2 times compared with the first day of the stress. The decline in assimilation activity continued even after the resumption of normal irrigation (at BBCH 75 stage 1.9 times lower compared with BBCH 71). As noted above, at BBCH 77 stage the leaves of this variety practically lost chlorophyll, therefore, gas exchange was not determined in them.

The impact of drought on $\mathrm{CO}_{2}$ assimilation was irreversible in both varieties. That indicates on stress-induced damage to the photosynthetic apparatus enzymes and structural proteins and their degradation [32]. This is confirmed by data on the changes in leaf transpiration rate after drought (Fig. 3). Thus in Podolyanka, transpiration rate during the period of drought was lower than control by $31-34 \%$, however, after the resumption of irrigation, it was almost recovered to the control values. Therefore, a decrease in the photosynthetic rate during the drought period might be well explained by a decrease in stomatal conductance, but an increase in it that occurred after the termination of the watering limitation did not lead to a corresponding restoration of $\mathrm{CO}_{2}$ assimilation activity. Drought impact on transpiration rate in Natalka variety was much stronger. Nevertheless, the treated plants of the Natalka variety after normal watering restitution had the same transpiration rate as at the end of drought period however photosynthesis rate continued to decline.
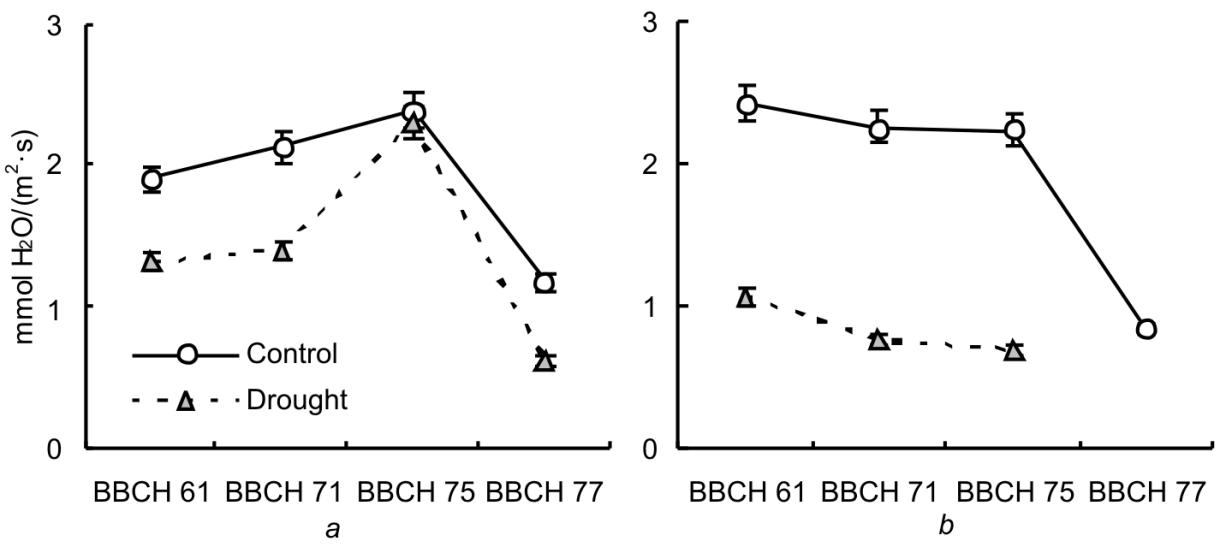

Fig. 3. The transpiration rate in the flag leaves of control and drought-treated (during $\mathrm{BBCH}$ 61-71 stages) wheat plants: $a-$ Podolyanka, $b-$ Natalka 
It can be assumed that senescence processes and associated nitrogencontaining compounds remobilization, both under normal conditions and accelerated by a stressor, affect primarily the photosynthetic apparatus of the mesophyll cells and only then - stomata. This is evidenced by the fact that in the control plants of both varieties during the period of $\mathrm{BBCH} 75-$ 77 stages, the transpiration rate decreased on average 2.5 times, while the photosynthetic rate decreased by 3.5-4 times. A smaller dependence of stomata functional state on the nitrogen status of the leaf, compared with the photosynthetic apparatus, was noted by us earlier in experiments with different levels of mineral nutrition [33].

In general, the flag leaves photosynthetic apparatus of Natalka variety plants showed itself to be much less resistant to drought compared to the Podolyanka variety. Obviously in the first variety, the stress-induced senescence processes started earlier and exacerbated direct drought negative impact on the $\mathrm{CO}_{2}$ assimilation than in the second. Perhaps, one of the reasons for this was genotypic peculiarities of the Natalka variety noted above.

This assumption is confirmed by the results of determination of Rubisco content in leaves of control and treated plants. Fig. 4 shows that drought decreased sharply the content of this enzyme in both varieties, while Rubisco content in control plants only showed a tendency to decrease (Podolyanka variety) or even slightly increased (Natalka variety). When the soil moisture was restored to optimal (BBCH 73 stage), enzyme amount in the Podolyanka variety stabilized at the level corresponding to the end of the drought period. At the same time, Rubisco content in plants of Natalka variety continued to decline and at BBCH 75 stage it approached zero. Rubisco content in treated plants of Podolyanka variety during post-stress period was much higher than in Natalka variety and remained quite detectable at $\mathrm{BBCH} 77$ stage, when leaf of treated plants of Natalka variety practically lost this protein.

As it is known, Rubisco is a key enzyme for $\mathrm{CO}_{2}$ assimilation in the Calvin cycle and it amount in leaf is much larger than other proteins [33]. According to some authors, this protein, accumulating in excess amounts,

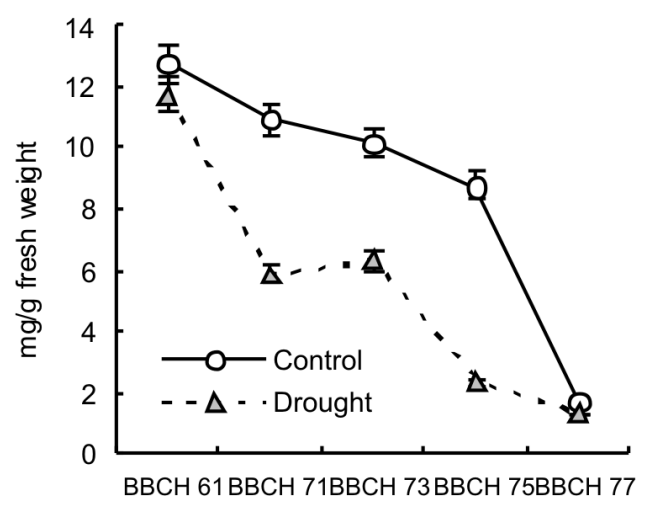

a

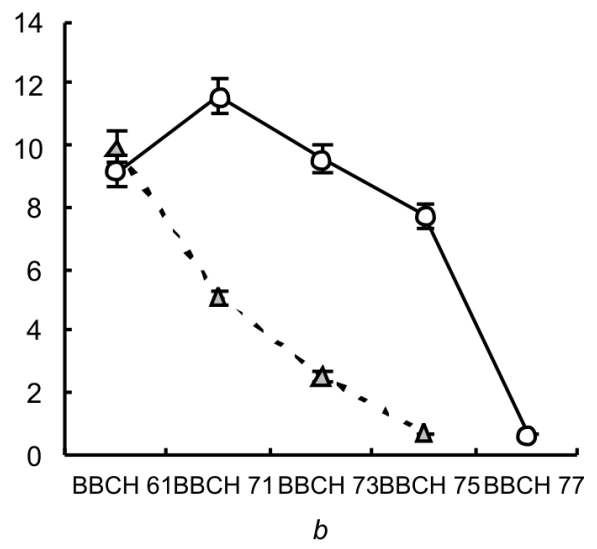

b

Fig. 4. The Rubisco content in the flag leaves of control and drought-treated (during BBCH 61-71 stages) wheat plants: $a-$ Podolyanka, $b-$ Natalka 
serves as a kind of organic nitrogen storage, which is remobilized into the grain during its filling [34].

There are contradictory in the literature concerning drought effect on Rubisco content: some studies shown diminishing while others reported no effect or even increase in enzyme content under drought [35]. It can be assumed that a decrease in the Rubisco content in plants during the drought period was provoked by assimilates deficiency due to decrease in $\mathrm{CO}_{2}$ assimilation. There is growing bulk of evidences on important protective role of drought-induced autophagy involving particularly Rubisco degradation [36]. Autophagy can provide raw materials for synthesis protective proteins and compounds (e.g. osmolites), as well as remove damaged proteins. Under these conditions, Rubisco reserves in the leaf may serve as a major source of organic carbon and nitrogen for protective changes in cell metabolism to ensure the vital processes in the plant.

The further drop in Rubisco content after the resumption of normal watering in Natalka variety plants, in our opinion, indicates the continue of drought-induced irreversible degradation processes associated with senescence. The stabilization of Rubisco content in the leaves of treated plants of Podolyanka after the drought termination, but not recovery as it was found for transpiration rate, points irreversible damage to photosynthetic apparatus yet without senescence development.

One of the nodal components that lie at the intersection of many signaling systems in the plants are ROS and especialy hydrogen peroxide. Today, it is known that this ROS plays the important role of signaling molecule, triggering a cascade of reactions related to the response to various stressors [37]. Under normal conditions, $\mathrm{H}_{2} \mathrm{O}_{2}$ is the product of many metabolic reactions and is detoxified by a number of antioxidant enzymes. Any violation of the homeostasis of these reactions under the stressor influence is accompanied by an increase in the $\mathrm{H}_{2} \mathrm{O}_{2}$ formation and induction of protective mechanisms, including activation of antioxidant enzymes.

The processes of macromolecules and cell structures degradation, specific for plant vegetative organs natural senescence, and the further remobilization of biologically valuable substances into storage organs are also accompanied by an increase in the $\mathrm{H}_{2} \mathrm{O}_{2}$ formation [10, 12]. Therefore, an increase in the $\mathrm{H}_{2} \mathrm{O}_{2}$ concentration under stress can untimely start and accelerate the senescence processes in plants, especially if they are «genotypically ready» to this [38].

Chloroplasts are one of the main $\mathrm{H}_{2} \mathrm{O}_{2}$ sources in photosynthetic cell. During the functioning of the photosynthetic electron transport chain of which, some electrons can be transferred to molecular oxygen with the formation of a superoxide anion radical [12]. The latter is a very dangerous ROS, the detoxification of which is carried out by SOD. As a result of reaction catalyzed by this enzyme, $\mathrm{H}_{2} \mathrm{O}_{2}$ is formed, which is reduced by APO to water. Under the influence of stressors, especially such as drought, the superoxide anion radical formation increases with a corresponding increase in the $\mathrm{H}_{2} \mathrm{O}_{2}$ formation. Chloroplast enzymatic antioxidant defense systems typically respond to this by increasing their activity to limit the excessive ROS formation [39]. 

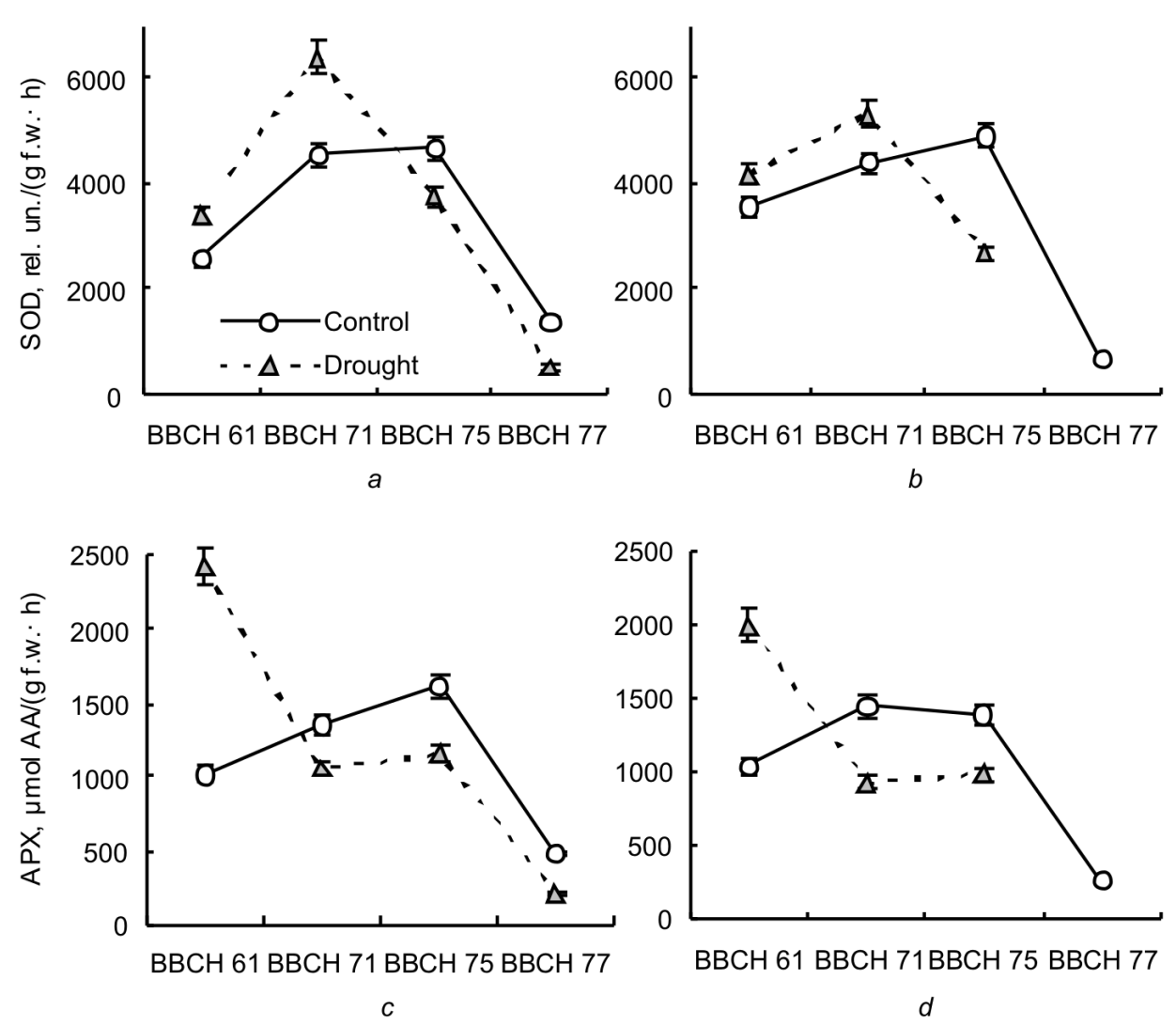

Fig. 5. The chloroplast $\operatorname{SOD}(a, b)$ and $\operatorname{APX}(c, d)$ activity in the flag leaves of control and drought-treated (during BBCH 61-71 stages) wheat plants: $a, c-$ Podolyanka; $b, d-$ Natalka. AA - ascorbic acid; f.w. - fresh weight

Our data on the chloroplast SOD and APO activity in the flag leaves of control wheat plants indicate that these enzymes functioned almost synchronously (Fig. 5). In both varieties, a gradual increase in their activity during $\mathrm{BBCH}$ 61-75 stages had been observed with a subsequent sharp decrease. This dynamics is obviously due to the increased ROS formation as the degradation processes accompanying senescence develop. A sharp drop in enzymes activity is associated with the final breakdown of proteins that ensure the vital activity of leaf cells (remobilization is an active process), and their death.

In the plants of Podolyanka variety on the first day of drought, the SOD activity significant increase compared with the control was observed, and even stronger - APO. After a week of plants stay at soil moisture of $30 \%$ FC, the SOD activity increased even more, and the APO activity decreased under the control level. After the resumption of normal irrigation, the SOD activity sharply decreased, and the APO activity remained unchanged. At the stage of late milk ripeness (BBCH 77), in experimental plants a synchronous with control decrease in the activity of both enzymes was observed, but at a lower level.

In Natalka variety, the dynamics of the chloroplast SOD and APO activity in the leaves of drought-treated plants was generally identical to that described above, with the only difference being that the increase in SOD acti- 
vity during the drought period was not as strong as in Podolyanka variety, and the subsequent drop was almost twofold compared with control (in Podolyanka - only $20 \%$ ).

So, at the beginning of the drought, a simultaneous increase in the chloroplast SOD and APO activity occurred, while a week later, at a background of further increase in the SOD activity, a decrease in the APO activity was observed. Only after soil moisture restoration to the optimum, the SOD activity also decreased, i.e. again synchronized with the APO. The increase in SOD activity during the drought period is most likely related to increased superoxide anion radical formation. At this, a decrease in APO activity should lead to a rise in the amount of $\mathrm{H}_{2} \mathrm{O}_{2}$, however it should be noted that in plant cells there are many other $\mathrm{H}_{2} \mathrm{O}_{2}$ detoxification systems - catalase, a large family of peroxidases, etc., which are also activated under stressful conditions.

Stress-induced damage to photosynthetic apparatus and accelerated leaves senescence led to a decrease in the biological and grain productivity of plants treated by drought during the flowering period, and these were more pronounced in the Natalka variety comparing to Podolyanka variety (Tables 1 and 2). Thus, the main shoot grain productivity in treated plants of the Podolyanka variety decreased by $15 \%$ compared to the control, while in Natalka variety it decreased by $40 \%$. This was mainly due to a reduction in the grain fullness, apparently as a result of assimilates deficiency during their filling caused by irreversible damage to the photosynthetic rate, exacerbated in Natalka variety by accelerating senescence under the stressor influence. The grain number in this case decreased insignificantly. Grain productivity per whole plant declined compared to control even more than this for main shoot due to a decrease not only in the 1000 grains weight but also in grain number resulted from reduction in productive tillering. Undoubtedly, the latter is also associated with lessening assimilates availability in treated plants. Decline in grain productivity was associated with significant decrease in the harvest index of drought-treated plants: in the Podolyanka variety by $18 \%$, in the Natalka variety - by $25 \%$.

TABLE 1. Productivity (calculated on dry matter) of main shoot of wheat plants subjected to drought at stages of flowering-kernel watery ripe $(B B C H 61-71)(x \pm S E ; n=20)$

\begin{tabular}{|c|c|c|c|c|}
\hline Variant & $\begin{array}{l}\text { Total weight, } \\
g\end{array}$ & Grain weight, $g$ & Grain number, pcs & $\begin{array}{l}1000 \text { grains } \\
\text { weight, } g\end{array}$ \\
\hline \multicolumn{5}{|c|}{ Podolyanka } \\
\hline Control & $2.78 \pm 0.08$ & $1.43 \pm 0.06$ & $33.1 \pm 1.1$ & $43.3 \pm 1.3$ \\
\hline Drought & $2.64 \pm 0.13$ & $1.21 \pm 0.10$ & $31.8 \pm 1.3$ & $37.0 \pm 1.8$ \\
\hline $\begin{array}{l}\% \text { relative to } \\
\text { control }\end{array}$ & 94.9 & 84.5 & 96.2 & 85.3 \\
\hline \multicolumn{5}{|c|}{ Natalka } \\
\hline Control & $3.16 \pm 0.09$ & $1.55 \pm 0.07$ & $34.3 \pm 1.1$ & $45.3 \pm 1.2$ \\
\hline Drought & $2.43 \pm 0.12$ & $0.93 \pm 0.07$ & $33.4 \pm 1.5$ & $27.7 \pm 1.5$ \\
\hline $\begin{array}{l}\% \text { relative to } \\
\text { control }\end{array}$ & 77.1 & 60.1 & 97.4 & 61.2 \\
\hline
\end{tabular}


TABLE 2. Productivity (calculated on dry matter) of whole wheat plants subjected to drought at stages of flowering-kernel watery ripe $(\mathrm{BBCH} 61-71)(x \pm S E ; n=20)$

\begin{tabular}{|c|c|c|c|c|c|c|c|}
\hline Variant & $\begin{array}{c}\text { Total } \\
\text { weight, } g\end{array}$ & $\begin{array}{c}\text { Grain } \\
\text { weight, } g\end{array}$ & $\begin{array}{l}\text { Grain } \\
\text { number, } \\
\text { pcs }\end{array}$ & $\begin{array}{c}1000 \\
\text { grains } \\
\text { weight, } g\end{array}$ & $\begin{array}{l}\text { Harvest } \\
\text { index }\end{array}$ & $\begin{array}{c}\text { Total } \\
\text { shoots } \\
\text { number, } \\
\text { pcs }\end{array}$ & $\begin{array}{c}\text { Productive } \\
\text { shoots } \\
\text { number, } \\
\text { pcs }\end{array}$ \\
\hline \multicolumn{8}{|c|}{ Podolyanka } \\
\hline Control & $5.06 \pm 0.51$ & $2.44 \pm 0.24$ & $61.9 \pm 6.2$ & $39.5 \pm 1.0$ & $0.49 \pm 0.01$ & $2.53 \pm 0.28$ & $2.47 \pm 0.28$ \\
\hline Drought & $4.33 \pm 0.35$ & $1.78 \pm 0.20$ & $47.7 \pm 4.4$ & $36.1 \pm 1.5$ & $0.40 \pm 0.02$ & $2.83 \pm 0.21$ & $2.17 \pm 0.16$ \\
\hline $\begin{array}{l}\% \text { relative } \\
\text { to control }\end{array}$ & 85.6 & 72.8 & 77.0 & 91.4 & 82.0 & 112.2 & 87.6 \\
\hline \multicolumn{8}{|c|}{ Natalka } \\
\hline Control & $5.35 \pm 0.34$ & $2.48 \pm 0.19$ & $63.0 \pm 4.8$ & $39.9 \pm 1.1$ & $0.46 \pm 0.01$ & $2.58 \pm 0.17$ & $2.32 \pm 0.15$ \\
\hline Drought & $3.60 \pm 0.30$ & $1.26 \pm 0.12$ & $47.8 \pm 3.7$ & $25.9 \pm 1.3$ & $0.34 \pm 0.02$ & $2.18 \pm 0.23$ & $1.86 \pm 0.20$ \\
\hline $\begin{array}{l}\% \text { relative } \\
\text { to control }\end{array}$ & 67.2 & 50.8 & 75.8 & 64.8 & 74.6 & 84.6 & 80.5 \\
\hline
\end{tabular}

In this regard, it should be noted that under drought treatment during the early reproductive period (booting stages), when it is still far from the start of natural senescence processes, negative effect of stress may be compensated after normal watering resumption through physiological, biochemical, and morphogenetic repair mechanisms (for example increased productive tillering), which was previously shown by us [40] and other authors [41].

Thus, our results show that transient one-week drought during flowering stage not only inhibited $\mathrm{CO}_{2}$ assimilation but also accelerated senescence processes in wheat plants causing the photosynthetic apparatus proteins degradation associated with the nitrogen-containing compounds remobilization into grain. This enhances the stressor negative impact on the plant organism so that after stress termination, physiological and biochemical parameters are not restored to the values of control plants that were all time under optimal moisture supply. Reduced supply of plants with assimilates during drought period due to photosynthesis inhibition and during post-stress period due to photosynthetic apparatus senescence and degradation ultimately leads to a decrease in their grain productivity. All these processes were much more pronounced in plants of the high-protein variety Natalka with a genetically programmed earlier start of the nitrogencontaining compounds remobilization from leaves than in Podolyanka variety. The drought-tolerant variety Podolyanka keep ability to maintain much higher $\mathrm{CO}_{2}$ assimilation activity during drought period and to preserve photosynthetic apparatus from early induction of senescence due to likely more efficient chloroplast antioxidant defense systems, thereby gaining a better assimilates supply for yield formation.

\section{REFERENCES}

1. Morgun, V.V. (2017). Contribution of plant physiology and genetics to food security of our country. In: Plant Physiology: Achievements and new directions of development, Vol. 1, (pp. 9-13), Logos, Kyiv [in Ukrainian]. 
2. Gregersen, P.L., Culetic, A., Boschian, L. \& Krupinska, K. (2013). Plant senescence and crop productivity. Plant Mol. Biol., 82, pp. 603-622. https://doi.org/10.1007/s11103013-0013-8

3. Gepstein, S. \& Glick, B.R. (2013). Strategies to ameliorate abiotic stress-induced plant senescence. Plant Mol. Biol., 82, pp. 623-633. https://doi.org/10.1007/s11103-0130038-Z

4. Guo, Y. (2013). Towards systems biological understanding of leaf senescence. Plant Mol. Biol., 82, pp. 519-528. https://doi.org/10.1007/s11103-012-9974-2

5. Sade, N., del Mar Rubio-Wilhelmi, M., Umnajkitikorn, K. \& Blumwald, E. (2018). Stress-induced senescence and plant tolerance to abiotic stress. J. Exp. Bot., 69, No. 4, pp. 845-853. https://doi.org/10.1093/jxb/erx235

6. Hortensteiner, S. (2013). Update on the biochemistry of chlorophyll breakdown. Plant Mol. Biol., 82, pp. 505-517. https://doi.org/10.1007/s11103-012-9940-Z

7. Avila-Ospina, L., Moison, M., Yoshimoto, K. \& Masclaux-Daubresse, C. (2014). Autophagy, plant senescence, and nutrient recycling. J. Exp. Bot., 65, No. 14, pp. 37993811. https://doi.org/10.1093/jxb/eru039

8. Have, M., Marmagne, A., Chardon, F. \& Masclaux-Daubresse, C. (2017). Nitrogen remobilization during leaf senescence: lessons from Arabidopsis to crops. J. Exp. Bot., 68, No. 10, pp. 2513-2529. https://doi.org/10.1093/jxb/erw365

9. Avin-Wittenberg, T., Baluska, F., Bozhkov, P.V., Elander, P.H., Fernie, A.R., Galili, G., Hassan, A., Hofius, D., Isono, E., Le Bars, R., Masclaux-Daubresse, C., Minina, E.A., Peled-Zehavi, H., Coll, N.S., Sandalio, L.M., Satiat-Jeunemaitre, B., Sirko, A., Testillano, P.S. \& Batoko, H. (2018). Autophagy-related approaches for improving nutrient use efficiency and crop yield protection. J. Exp. Bot., 69, No. 6, pp. 1335-1353. https://doi.org/10.1093/jxb/ery069

10. Khanna-Chopra, R. (2012). Leaf senescence and abiotic stresses share reactive oxygen species-mediated chloroplast degradation. Protoplasma, 249, pp. 469-481. https://doi.org/10.1007/s00709-011-0308-z

11. De Simone, V., Soccio, M., Borrelli, G.M., Pastore, D. \& Trono, D. (2014). Stay-green trait-antioxidant status interrelationship in durum wheat (Triticum durum) flag leaf during post-flowering. J. Plant Res., 127, pp. 159-171. https://doi.org/10.1007/s10265013-0584-0

12. Krieger-Liszkay, A., Krupinska, K. \& Shimakawa, G. (2019). The impact of photosynthesis on initiation of leaf senescence. Physiologia Plantarum, 166, pp. 148-164. https://doi.org/10.1111/ppl.12921

13. Semwal, V.K. \& Khanna-Chopra, R. (2018). Reproductive sink enhanced drought induced senescence in wheat fertile line is associated with loss of antioxidant competence compared to its CMS line. Physiology and Molecular Biology of Plants, 24, pp. 591-604. https://doi.org/10.1007/s12298-018-0549-9

14. Jibran, R., Hunter, D.A. \& Dijkwel, P.P. (2013). Hormonal regulation of leaf senescence through integration of developmental and stress signals. Plant Mol. Biol., 82, pp. 547561. https://doi.org/10.1007/s11103-013-0043-2

15. Yang, J., Zhang, J., Wang, Z., Zhu, Q. \& Liu, J. (2003). Involvement of abscisic acid and cytokinins in the senescence and remobilization of carbon reserves in wheat subjected to water stress during grain filling. Plant, Cell Environ., 26, pp. 1621-1631. https://doi.org/10.1046/j.1365-3040.2003.01081.x

16. Lee, S., Seo, P.J., Lee, H.J. \& Park, C.M. (2012). A NAC transcription factor NTL4 promotes reactive oxygen species production during drought-induced leaf senescence in Arabidopsis. Plant J., 70, pp. 831-844. https://doi.org/10.1111/j.1365313X.2012.04932.X

17. Wellburn, A.R. (1994). The spectral determination of chlorophylls a and b, as well as total carotenoids, using various solvents with spectrophotometers of different resolution. J. Plant Physiol., 144, pp. 307-313. https://doi.org/10.1016/S01761617(11)81192-2

18. Mokronosov, A.T. \& Kovalev, A.G. (Eds.). (1989). Photosynthesis and Bioproductivity: Methods of Determination. Agropromizdat, Moskow [in Russian]. 
19. Aranjuelo, I., Perez, P., Hernandez, L., Irigoyen, J.J., Zita, G., Martinez-Carrasco, R. \& Sanchez-Diaz, M. (2005). The response of nodulated alfalfa to water supply, temperature and elevated $\mathrm{CO}_{2}$ : photosynthetic downregulation. Physiol. Plant., 123, No. 3, pp. 348-358. https://doi.org/10.1111/j.1399-3054.2005.00459.x

20. Laemmli, U.K. (1970). Cleavage of structural proteins during the assembly of the head of bacteriophage T4. Nature, 227, No. 5259, pp. 680-685. https:// doi.org/10.1038/227680a0

21. Giannopolitis, C.N. \& Ries, S.K. (1977). Superoxide dismutase. Occurrence in higher plants. Plant Physiol., 59 (2), pp. 309-314. https://doi.org/10.1104/pp.59.2.309

22. Chen, G.-X. \& Asada, K. (1989). Ascorbate peroxidase in tea leaves: occurrence of two isozymes and the differences in their and molecular properties. Plant and Cell Physiol., 30 (7), pp. 987-998. https://doi.org/10.1093/oxfordjournals.pcp.a077844

23. Morgun, V.V., Sanin, Y.V. \& Schwartau, V.V. (2015). The club 100 centners. Winter wheat varieties of the Institute of Plant Physiology and Genetics of the National Academy of Sciences of Ukraine and the protection system of Syngenta. Kyiv: Logos [in Ukrainian].

24. Gaju, O., Allard, V., Martre, P., Le Gouis, J., Moreau, D., Bogard, M., Hubbart, S. \& Foulkes, M.J. (2014). Nitrogen partitioning and remobilization in relation to leaf senescence, grain yield and grain nitrogen concentration in wheat cultivars. Field Crop Research, 155, pp. 213-223. http:/ dx.doi.org/10.1016/j.fcr.2013.09.003

25. Distelfeld, A., Avni, R. \& Fischer, A. (2014). Senescence, nutrient remobilization, and yield in wheat and barley. J. Exp. Bot., 65, pp. 3783-3798. doi: 10.1093/jxb/ert477

26. Zhang, H. \& Zhou, C. (2013). Signal transduction in leaf senescence. Plant Mol. Biol., 82, pp. 539-545. https://doi.org/10.1007/s11103-012-9980-4

27. Christopher, J.T., Christopher, M.J., Borrell, A.K., Fletcher, S. \& Chenu, K. (2016). Stay-green traits to improve wheat adaptation in well-watered and water-limited environments. J. Exp. Bot., 67, No. 17, pp. 5159-5172. https://doi.org/10. 1093/jxb/erw276

28. Ghodke, P.H., Ramakrishnan, S., Shirsat, D.V., Vani, G.K. \& Arora, A. (2019). Morphological characterization of wheat genotypes for stay green and physiological traits by multivariate analysis under drought stress. Plant Physiology Reports, 24(3), pp. 305-315. https://doi.org/10.1007/s40502-019-00458-8

29. Bogard, M., Jourdan, M., Allard, V., Martre, P., Perretant, M.R., Ravel, C., Heumez, E., Orford, S., Snape, J., Griffiths, S., Gaju, O., Foulkes, J. \& Le Gouis, J. (2011). Anthesis date mainly explained correlations between post-anthesis leaf senescence, grain yield, and grain protein concentration in a winter wheat population segregating for flowering time QTLs. J. Exp. Bot., 62(10), pp. 3621-3636. https://doi.org/10.1093/jxb/err061

30. Gong, Y.H., Zhang, J., Gao, J.F., Lu, J.Y. \& Wang, J.R. (2005). Slow export of photoassimilate from stay-green leaves during late grain-filling stage in hybrid winter wheat (Triticum aestivum L.). J. Agron. Crop Sci., 191, No. 4, pp. 292-299. https://doi.org/ 10.1111/j.1439-037X.2005.00173.x

31. Chauhan, S., Srivalli, S., Nautiyal, A.R. \& Khanna-Chopra, R. (2009). Wheat cultivars differing in heat tolerance show a differential response to monocarpic senescence under high-temperature stress and the involvement of serine proteases. Photosynthetica, 47(4), pp. 536-547.

32. Feller, U. (2016). Drought stress and carbon assimilation in a warming climate: Reversible and irreversible impacts. J. Plant Physiol., 203, pp. 84-94. http:// dx.doi.org/10.1016/j.jplph.2016.04.002

33. Kiriziy, D.A., Stasik, O.O., Pryadkina, G.A. \& Shadchina, T.M. (2014). Photosynthesis, Vol. 2, Assimilation of $\mathrm{CO}_{2}$ and the mechanisms of its regulation. Logos, Kyiv [in Russian]

34. Feller, U., Anders, I. \& Mae, T. (2008). Rubiscolytics: fate of Rubisco after its enzymatic function in a cell is terminated. J. Exp. Bot., 59, No. 7, pp. 1615-1624 https://doi.org/10.1093/jxb/erm242

35. Galmes, J., Aranjuelo, I., Medrano, H. \& Flexas, J. (2013). Variation in Rubisco content and activity under variable climatic factors. Photosynth. Res., 117, pp.73-90. https://doi.org/10.1007/s11120-013-9861-y 
36. Wang, P., Mugume, Y. \& Bassham, D. C. (2018). New advances in autophagy in plants: Regulation, selectivity and function. Seminars in Cell \& Developmental Biology, 80, pp. 113-122. https://doi.org/10.1016/j.semcdb.2017.07.018

37. Kolupaev, Yu.E., \& Kokorev, A.I. (2019). Antioxidant system and plant resistance to water deficit. Fiziol. rast. genet., 51(1), pp. 28-54 [in Russian]. https:// doi.org/10.15407/frg2019.01.02

38. Cui, M.H., Ok, S.H., Yoo, K.S., Jung, K.W., Yoo, S.D. \& Shin, J.S. (2013). An Arabidopsis cell growth defect factor-related protein, CRS, promotes plant senescence by increasing the production of hydrogen peroxide. Plant Cell Physiol., 54, pp. 155-167. https://doi.org/10.1093/pcp/pcs161

39. Morgun, V.V., Stasik, O.O., Kiriziy, D.A. \& Sokolovska-Sergiienko, O.G. (2019). Effect of drought on photosynthetic apparatus, activity of antioxidant enzymes, and productivity of modern winter wheat varieties. Regulatory Mechanisms in Biosystems, 10(1), pp. 16-25. https://doi.org/10.15421/021903

40. Morgun, V.V., Stasik, O.O., Kiriziy, D.A., Sokolovska-Sergiienko, O.G. \& Makharynska, N.M. (2019). Effects of drought at different periods of wheat development on the leaf photosynthetic apparatus and productivity. Regulatory Mechanisms in Biosystems, 10(4), pp. 406-414. https:/ doi.org/10.15421/021961

41. Abid, M., Tian, Z., Ata-Ul-Karim, S.T., Wang, F., Liu, Y., Zahoor, R., Jiang, D. \& Dai, T. (2016). Adaptation to and recovery from drought stress at vegetative stages in wheat (Triticum aestivum) cultivars. Functional Plant Biology, 43, pp. 1159-1169. http://dx.doi.org/10.1071/FP16150

Received 01.10.2020

\section{ВПЛИВ ПОСУХИ НА АКТИВНІСТЬ ФОТОСИНТЕТИЧНОГО АПАРАТУ, ШВИДКІІСТЬ СТАРЇННЯ І̇ ПРОДУКТИВНЇСТЬ РОСЛИН ПШЕНИЦІ}

\section{О.О. Стасик, Д.А. Кірізій, О.Г. Соколовська-Сергієнко, О.Ю. Бондаренко}

Їнститут фізіології рослин і генетики Національної академії наук України 03022 Київ, вул. Васильківська, 31/17, Україна

e-mail: phot-ecol@ifrg.kiev.ua

В умовах вегетаційного досліду вивчали вплив грунтової посухи у фазі цвітіння на функціональний стан фотосинтетичного апарату і ферментативних систем антиоксидантного захисту хлоропластів прапорцевого листка в репродуктивний період, а також продуктивність рослин озимої пшениці високобілкового сорту Наталка і посухостійкого сорту Подолянка. Для контрольних рослин упродовж всієї вегетації вологість грунту підтримували на рівні 60-70\% повної вологоємності (ПВ). Для дослідних рослин посуху (вологість грунту 30 \% ПВ) створювали протягом 7 діб, охоплюючи період цвітіння-водяниста стиглість зерна (ВВСН 61-71). Після цього полив рослин відновили до контрольного рівня, який підтримували до кінця вегетації. Вимірювання вмісту хлорофілу і Рубіско, активності антиоксидантних ферментів хлоропластів, а також показників асиміляції $\mathrm{CO}_{2}$ і транспірації проводили на прапорцевому листку на третій день припинення поливу (в перший день досягнення вологості грунту $30 \%$ ПВ, ВВСН 61), в кінці періоду посухи (сьомий день при $30 \%$ ПВ, ВВСН 71) і після відновлення поливу - у фази середньої (ВВСН 75) і пізньої (ВВСН 77) молочної стиглості. Складові зернової продуктивності рослин визначали зважуванням повітряно-сухого матеріалу за повної стиглості зерна. Виявлено, що водний стрес під час цвітіння пригнічував асиміляцію $\mathrm{CO}_{2}$ і прискорював індукцію процесів старіння у рослин пшениці, пов'язаних із деградацією фотосинтетичного апарату, що проявлялося у швидшому онтогенетичному падінні вмісту хлорофілу і Рубіско, а також у прискоренні зниження фотосинтетичної активності листків. Це посилило вплив посухи на рослинний організм, так що після відновлення оптимального поливу фізіологічні та біохімічні характеристики не відновлювалися до значень 
контрольних рослин, які весь час перебували за умов оптимального зволоження. Спричинене стресом передчасне старіння призвело до зниження забезпеченості рослин асимілятами i, в кінцевому підсумку, до зменшення зернової продуктивності. Вплив посухи на фотосинтетичну активність листків i, особливо, на індукцію старіння було більш виражено у високобілкового сорту пшениці Наталка, з генетично запрограмованим ранішим початком ремобілізації азотовмісних сполук із листків, ніж у сорту Подолянка. Посухостійкий сорт Подолянка зберігав здатність підтримувати набагато вищу активність асиміляції $\mathrm{CO}_{2}$ в період посухи і запобігати ранній індукції старіння фотосинтетичного апарату, ймовірно, завдяки ефективнішим системам антиоксидантного захисту хлоропластів, тим самим забезпечуючи краще постачання асимілятами для формування врожаю.

Ключові слова: Triticum aestivum L., посуха, старіння, швидкість асиміляції $\mathrm{CO}_{2}$, Рубіско, антиоксидантні ферменти, продуктивність. 